\title{
The Impact of Selected Pesticides on Honey Bees
}

\author{
Pawel Migdal'*, Adam Roman', Ewa Popiela-Pleban', \\ Monika Kowalska-Góralska², Sebastian Opaliński ${ }^{1}$ \\ ${ }^{1}$ Department of Environment, Hygiene and Animal Welfare, Wrocław University of Environmental and Life Sciences, \\ 51-630 Wrocław, Poland \\ ${ }^{2}$ Institute of Biology, Wrocław University of Environmental and Life Sciences, \\ 51-630 Wrocław, Poland
}

Received: 2 March 2017

Accepted: 28 May 2017

\begin{abstract}
The presence of honey bee in the environment has a significant impact on global agricultural production. While searching for pollen and nectar, the bee is often exposed to several contaminants such as plant protection products. The aim of this study was to assess the impact of selected pesticides from various groups (fungicides, herbicides, insecticides) on the way the bees harvested food as well as on their behavior, survival rate and the concentration of certain elements in the organisms of bee. The concentration possibly similar to this applied in agriculture and recommended by the manufacturers, were used. The research material was analyzed in terms of the presence of trace elements (manganese, copper, iron, nickel, zinc, lead, cadmium) of different toxicity. The study clearly indicates that selected pesticides used for the purpose of plant protection and plant cultivation may adversely on bees' behavior and accumulation of trace elements in their body. Among the tested pesticides particular attention should be paid to fungicides that are not commonly tested for their effects on the honey organ. In own studies showed, their effect significantly changed the content of copper and negatively affected the survival of the bees.
\end{abstract}

Keywords: behavior, trace elements, pesticides, honey bee

\section{Introduction}

Intense development of agriculture and animal production has caused exposure to substances with which bees have never before come into contact. The increasing demand for food has forced farmers to use more mineral fertilizers and pesticides to generate higher yields [1]. The

*e-mail: pawel.migdal@upwr.edu.pl residues of these substances in the form of contaminants are then transferred into grains, vegetables, and fruit [2]. They have also been discovered in herbs such as mint (Mentha) or lemon balm (Melissa officinalis) [3]. While working on flowers, bees are exposed to direct and indirect contact with pesticides which, depending on the mode of action and the concentration of active substance, can lead to sudden death of pollinating insects or cause death within a couple of hours following exposure [4]. It becomes dangerous when the level of pesticides or their residues in a beehive becomes 
high enough to adversely affect the functioning and development of larvae [5]. This causes the bees to become more susceptible to bacterial infections. This is particularly risky in the case of American foulbrood caused by Paenibacillus larvae.

Weakened bees and a disorganized colony become more susceptible to this disease [6]. They also suffer more frequently from nosemosis, also known as bee dysentery, or varroosis [7]. Moreover, the microflora of bee intestines is affected [8]. Some pesticides trigger disorders of the digestive and endocrine systems, leading to distention of the abdomen, as a result of which the bees become slow and apathetic, showing difficulties with active flying [9]. Bees are highly susceptible to environmental changes and pollution, which is strongly reflected in the significant decrease of their survival rate [10].

The search for reasons for this phenomenon has established a new disease entity called colony collapse disorder (CCD). Several studies have indicated the important role of pesticides in the appearance and development of numerous pathological disorders in bee organisms [11]. Although it is still hard to find one cause of CCD, the significant impact of pesticides on its development cannot be questioned. Animals and their produce may also be used in the process of evaluating the level of environmental pollution. Honey bees ( $A$. mellifera) serve as a bioindicator of contamination with trace elements of toxic properties (copper, zinc, iron, tin cadmium, lead, arsenic, and aluminum) [12]. Bees constantly penetrate the environment seeking new produce and the raw materials necessary to provide for the functioning of their colony. Even though the aforementioned elements may appear in pesticides commonly used in agriculture, it is impossible to determine unequivocally whether their presence in bees and bee products originates in the environment or results from the contact between bees and pesticides.

Selected manganese $(\mathrm{Mn})$ negatively affects behavior and leads to disturbances in chitin synthesis, while copper $(\mathrm{Cu})$ is a natural component of the hemolymph of bees [13-14]. Lead $(\mathrm{Pb})$ and cadmium (Cd) are very toxic for animals and the environment [15]. Iron ( $\mathrm{Fe})$, nickel $(\mathrm{Ni})$, and zinc $(\mathrm{Zn})$ contaminants in the honey bee body can occur because of botanical origin, as well as anthropogenic factors around the colonies [16]. The scientific literature indicates that $\mathrm{Pb}, \mathrm{Cd}, \mathrm{Cu}, \mathrm{Mn}, \mathrm{Ni}, \mathrm{Zn}$, and $\mathrm{Fe}$ are the most important heavy metals, and studies show a tendency for their accumulation in living organisms [17-18]. Pesticides that contain metals as active substances influence the content of these elements in the organism of honey bees.

The aim of this study was to assess the impact of selected pesticides from various groups (fungicides, herbicides, insecticides) on bee behavior, survival rate, and the concentration of selected trace elements in their organisms.

\section{Material and Methods}

Laboratory tests were carried out from June to midAugust. The studied material consisted of honey bee workers (A. mellifera) of the Carniola race obtained from one bee colony to each repeat [19]. Ten-day-old worker bees were distributed into seven dietary treatments. They were transported to the laboratory where the container was left for $30 \mathrm{~min}$ (at about $26^{\circ} \mathrm{C}$ ). The bees were then rendered unconscious by exposure to ammonium nitrate. After about 30 seconds, the insects became unconscious for about 2-3 min, when they were moved to experimental cages at 160 individuals per cage. The cages were supplied with lids, each with two holes with $5 \mathrm{~cm}^{3}$ food dispensers containing test or control solutions. Bees were placed in identical cages of wood and glass with dimensions of $50 \times 150 \times 150 \mathrm{~mm}$. Inside each cage were placed frames with wax foundations (size approximately $120 \times 120 \mathrm{~mm}$ ) [20]. The cages were put in an incubator where constant temperature and humidity (the first 24 hours of experience T $35^{\circ} \mathrm{C}$, subsequently $27^{\circ} \mathrm{C}, \mathrm{H} 75 \%$ ) were maintained [21]. Throughout the study, bees were fed with $2 \mathrm{~mol} / \mathrm{dm}^{3}$ sugar syrup. The first $24 \mathrm{~h}$ were dedicated to adjusting to the new environmental conditions, feeding, and then - after removal of dead individuals - starting the actual experiment.

Each dietary treatment was divided into six replicates. Pesticides were selected in the manner allowing for double representation of each group (two kinds of insecticides, two herbicides, and two fungicides). The concentration of each pesticide was in accordance with the recommendation of the manufacturer. Each dose of pesticide was dissolved in $100 \mathrm{~cm}^{3}$ of sugar syrup ( $\left.2 \mathrm{moll} / \mathrm{dm}^{3}\right)$. Experimental groups were:

- Group K: control, pesticide-free sugar syrup.

- Group A: Miedzian 50WP (fungicide 1) with active substance of copper oxychloride- authorized for trade and distribution until 2019, dose $0.35 \mathrm{~g} / 100 \mathrm{~cm}^{3}$ of syrup.

- Group B: thiram granuflo 80WG (fungicide 2) main active ingredient thiram, authorized for use until 2020 , dose $0.60 \mathrm{~g} / 100 \mathrm{~cm}^{3}$ of syrup.

- Group C: Fastac 100EC (insecticide1) active substance $\alpha$-cyphermetrin, authorized for distribution until 2020 , dose $0.04 \mathrm{~cm}^{3} / 100 \mathrm{~cm}^{3}$ of syrup.

- Group D: Actara 25WG (insecticide 2) active substance thiamethoxam, authorized for trade until 2021 , dose $0.04 \mathrm{~g} / 100 \mathrm{~cm}^{3}$ of syrup.

- Group E: Basagran 480SL (herbicide 1) active substance bentazone, authorized for distribution until 2020 , dose $1.2 \mathrm{~cm}^{3} / 100 \mathrm{~cm}^{3}$ of syrup.

- Group F: Metafol 700SC (herbicide 2) active substance metamitron, authorized for production until 2016, dose $0.60 \mathrm{~cm}^{3} / 100 \mathrm{~cm}^{3}$ of syrup.

Every day the solutions in food dispensers were replaced with new ones in order to minimize the risk of chemical changes in the tested substances. Dead individuals were collected and stored in a freezer $\left(-20^{\circ} \mathrm{C}\right)$. After completion of the experiment the samples 
were defrosted and triturated using a ceramic crucible. Afterward the samples were transferred quantitatively to a petri dish and placed in a dryer laboratory for $8 \mathrm{~h}$ at $45^{\circ} \mathrm{C}$. In order to obtain precisely dried and homogenized samples, dried material was triturated and placed on RADWAG WPX 50S moisture balances, where it was dried to a constant weight at the same temperature as in the incubator. Each sample was weighed at $1 \mathrm{~g}$ (to the nearest $0.10 \mathrm{mg}$ ) and samples of biological material were weighed in Teflon dishes using a RADWAG WAS 220/X analytical balance. The samples were covered with $5 \mathrm{~cm}^{3}$ of spectrally pure $69 \%$ nitric acid (TRACEPUR EMD Millipore Corporation). These sample preparations were mineralized in ANTON PAAR MULTIWAVE 3000 microwave digestion for 30 minutes. The whole process lasted two hours.

After mineralization the obtained mineralisates were centrifuged and the content was moved into new Falcon tubes. The resulting mineralisates were analyzed quantitatively using flame atomic absorption spectrophotometry (AAS). Elements to which bees might be exposed in the natural environment and elements that appeared in the chemical structure of active substances of the pesticides were indicated. The indicated trace elements included $\mathrm{Cu}, \mathrm{Mn}, \mathrm{Fe}, \mathrm{Ni}, \mathrm{Cd}, \mathrm{Pb}$, and $\mathrm{Zn}$. Moreover, behavioral observation was carried out during the study. The results obtained in experimental groups were related to a control group. The following behavioral factors were taken into account: aggression, walking, grooming, reversal, immobility, and attempts to reconstruct comb foundations. If no irregularities were noticed during observation it was marked with '-' in the table, whereas any behavioral changes or dysfunctions were marked with a ' + ' (small), ' ++ ' (medium), or ' +++ ' (big). An assessment was made based on frequency of given behavior. Observations were carried out in 15-min periods for each group by two observers. The results obtained were analyzed statistically using Statistica for Windows v. 10.0. The mean, standard deviation, and relevance of differences between given groups were established. Statistical analysis was made based on Duncan test $(\mathrm{P} \leq 0.05)$.

\section{Results}

The highest intake of fodder was observed in Control Group K: $250.10 \mathrm{~mm}^{3}$ per one bee in 24 hours. This group presented the lowest daily mortality of bees at the average level of 1.92 individuals, which represents $1.20 \%$ of all bees in a given cage. The highest daily mortality $68.91 \%$ - was noticed in Group D, where the insecticide Actara 25WG was supplied. Daily fodder intake in this group was the lowest at $0.15 \mathrm{~mm}^{3}$ per individual (Table 1). In Group B, fed with the addition of the fungicide Thiram Granuflo 80WG, and in Group E, fed with the herbicide Basagran 480SL, similar syrup intakes of 16.78 and $16.16 \mathrm{~mm}^{3}$ per insect were observed. Daily mortality rate in these groups $(3.23 \%$ and $2.00 \%$, respectively)
Table 1. Daily intake of syrup and the mortality rate

\begin{tabular}{|c|c|c|c|}
\hline Group & $\begin{array}{c}\text { Syrup intake } \\
{\left[\mathrm{mm}^{3}\right] / \text { bee/24h }}\end{array}$ & $\begin{array}{c}\text { Mortality rate } \\
\text { bees/24h }\end{array}$ & $\begin{array}{c}\text { Time of } \\
\text { experiment } \\
{[\mathrm{h}]}\end{array}$ \\
\hline K & $250.10^{*}$ & $1.92 *$ & 168 \\
\hline A & 4.75 & 35.15 & 108 \\
\hline B & 16.78 & 5.17 & 168 \\
\hline C & 2.25 & 32.48 & 120 \\
\hline D & $0.15 * / * *$ & $110.25 * / * *$ & 36 \\
\hline E & $16.16 * *$ & $3.21 * *$ & 168 \\
\hline F & 13.87 & 13.00 & 168 \\
\hline
\end{tabular}

* differences between groups assessed highly significant on a level of $\mathrm{P} \leq 0.05$.

** differences between groups assessed highly significant on a level of $\mathrm{P} \leq 0.01$.

showed another resemblance (Table 1). In Group F the volume of syrup intake was slightly lower $\left(13.87 \mathrm{~mm}^{3}\right)$, whereas the mortality rate was three times as big and amounted to 13 individuals, representing $8.13 \%$ of all bees in this cage. Very low syrup income was observed in Groups A (fungicide Miedzian 50W) and C (insecticide Fastac 100EC) on the level of 4.75 and $2.25 \mathrm{~mm}^{3 /}$ bee, respectively. Remarkably, both groups showed very similar mortality rates.

The fewest behavioral changes were observed in the Control Group (Table 2). The bees were calm and did not show increased aggression during human interference in the cage. They made an effort to reconstruct the comb foundation, which is fairly natural. Generally, no behavioral irregularities were observed in relation to usual course of behavior in the colony from which the bees originated. It is therefore relevant to use this group as reference material for other test groups. The most significant changes were observed in the behavior of bees in Group D, fed with the additive of insecticide Actara $25 \mathrm{WG}$. Their behavior was typical for bees exposed to neonicotinoid pesticide. The second insecticide (Fastac 100EC) provided in Group C did not affect the insects' behavior.

Table 2. Evaluation of honey bee behavior

\begin{tabular}{|c|c|c|c|c|c|c|c|}
\hline \multirow{2}{*}{ Behavior } & \multicolumn{7}{|c|}{ Group } \\
\cline { 2 - 8 } & K & A & B & C & D & E & F \\
\hline Agrgession & - & ++ & + & - & +++ & +++ & ++ \\
\hline Walking & - & ++ & ++ & - & +++ & +++ & + \\
\hline Grooming & + & + & + & + & +++ & + & +++ \\
\hline Reversal & - & + & - & + & ++ & - & + \\
\hline Still & - & - & - & - & ++ & - & + \\
\hline Rebuild of comb & ++ & - & -1 & - & - & + & + \\
\hline
\end{tabular}

${ }^{1}$ bees cut the comb foundation 
Table 3. The concentration of trace elements

\begin{tabular}{|c|c|c|c|c|c|c|c|}
\hline \multirow{2}{*}{ Group } & \multicolumn{7}{|c|}{ The average contents $\left( \pm\right.$ SD) of chemical elements $\left[\mathrm{mg}^{\circ} \cdot \mathrm{kg}^{-1}\right]$} \\
\cline { 2 - 8 } & Manganese & Copper & Iron & Nickel & Zinc & Lead & Cadmium \\
\hline K & $58.80( \pm 2.21)^{\mathrm{ab}}$ & $27.70( \pm 1.65)^{\mathrm{b}}$ & $201.94( \pm 7.53)^{\mathrm{b}}$ & $0.68( \pm 0.15)^{\mathrm{c}}$ & $118.21( \pm 4.42)^{\mathrm{a}}$ & $4.59( \pm 0.72)$ & $0.2( \pm 0.08)$ \\
\hline A & $49.68( \pm 5.39)^{\mathrm{cd}}$ & $\begin{array}{c}2102.90 \\
( \pm 203.13)^{\mathrm{a}}\end{array}$ & $276.19( \pm 29.62)^{\mathrm{a}}$ & $3.18( \pm 0.97)^{\mathrm{a}}$ & $119.31( \pm 1.63)^{\mathrm{a}}$ & $4.78( \pm 0.43)$ & $0.15( \pm 0.08)$ \\
\hline B & $47.71( \pm 2.45)^{\mathrm{d}}$ & $32.24( \pm 3.13)$ & $188.03( \pm 8.12)^{\mathrm{bc}}$ & $2.10( \pm 0.09)^{\mathrm{b}}$ & $114.62( \pm 2.45)^{\mathrm{bc}}$ & $5.36( \pm 0.32)$ & $0.16( \pm 0.10)$ \\
\hline C & $51.25( \pm 2.33)^{\mathrm{cd}}$ & $30.44( \pm 0.43)$ & $171.26( \pm 2.68)^{\mathrm{c}}$ & $1.66( \pm 1.17)^{\mathrm{c}}$ & $119.71( \pm 1.34)^{\mathrm{a}}$ & $4.55( \pm 0.31)$ & $0.16( \pm 0.08)$ \\
\hline D & $60.17( \pm 1.35)^{\mathrm{a}}$ & $28.49( \pm 0.40)$ & $205.48( \pm 14.39)^{\mathrm{b}}$ & $3.33( \pm 1.09)^{\mathrm{a}}$ & $117.03( \pm 1.25)^{\mathrm{ab}}$ & $5.36( \pm 0.58)$ & $0.22( \pm 0.07)$ \\
\hline E & $46.73( \pm 0.4)^{\mathrm{d}}$ & $26.28( \pm 0.73)$ & $173.24( \pm 16.96)^{\mathrm{c}}$ & $1.58( \pm 0.35)^{\mathrm{bc}}$ & $112.26( \pm 1.09)^{\mathrm{c}}$ & $4.83( \pm 1.2)$ & $0.20( \pm 0.15)$ \\
\hline F & $54.30( \pm 7.3)^{\mathrm{c}}$ & $28.31( \pm 0.49)$ & $206.07( \pm 15.18)^{\mathrm{b}}$ & $2.44( \pm 0.94)^{\mathrm{ab}}$ & $118.52( \pm 1.823)^{\mathrm{a}}$ & $5.05( \pm 0.52)$ & $0.18( \pm 0.06)$ \\
\hline
\end{tabular}

$\mathrm{a}, \mathrm{b}, \mathrm{c}, \mathrm{d}$ - differences between the elements assessed highly significant on a level of $\mathrm{P} \leq 0.05$.

All behavioral factors were similar to the Control Group and reflected the low toxicity of this substance to bees. Although general behavioral changes were similar in Groups A, E, and F, different levels of intensity were observed. Increased aggression and mobility was noticed among bees in Group E, whereas in the other two groups they were on a low or middle level. The least significant changes were observed in Group B, fed with the addition of fungicide, where the behavior was similar to Control Group. Trace elements determined in their organisms are presented in Table 3. The largest fluctuation in concentration among all tested elements was observed in the concentration of copper - particularly in the case of Miedzian 50WP, as in that additive copper was one of the components of active substance $(\mathrm{CuOCl})$.

There is a clear connection between the presence of copper in provided fungicide and the increased level of copper in the organisms of bees. Said product caused mortality among bees at the rate of $17.47 \%$ of overall daily mortality, which means that a significant number of bees fed Miedzian 50WP would have been able to return to the hive. No statistically significant differences in the presence of copper were observed in other groups in reference to Control (Table 3). Cd appeared to be the least estimating element, as its amount was not detected at a representative level and in the sample containing Basagran 480SL the amount of cadmium was below the limit of quantification. Mn, another analyzed element, exhibited more variability than $\mathrm{Cu}$. The level of $\mathrm{Mn}$ in bees from groups $\mathrm{A}, \mathrm{B}, \mathrm{C}$, and $\mathrm{E}$ showed significant differences in reference to other groups. Bees in Groups $\mathrm{A}$ and $\mathrm{B}$ were fed syrup with the addition of fungicide, bees from Group C were fed insecticide Fastac 100 EC, and bees from Group E were fed herbicide Basagran 480 $\mathrm{SL}$. The level of $\mathrm{Mn}$ in given sample material was getting lower in comparison to Control, except for the bees fed the addition of Atacara $25 \mathrm{WG}$, where the level of said element increased by $2.33 \%$.

The concentration of $\mathrm{Fe}$ and $\mathrm{Cu}$ in tested bees presented the highest standard deviation among analyzed elements. The presence of iron in bees fed with the addition of various pesticides presented significant fluctuations. The impact of Miedzian 50 WP (Group A) stood out among all tested products. The concentration of iron in bees from the above-mentioned group increased more than in any other group and in reference to Control it increased by $36.77 \%$. Whereas in the case of bees from Groups $\mathrm{C}$ and E, fed with the addition of Fastac 100 EC and Basagran $480 \mathrm{SL}$, a significant decrease of iron concentration was observed. In all sample groups, where the bees were provided with the addition of pesticides, the amount of $\mathrm{Ni}$ was bigger than in Control. The highest level of said element was observed in group D, where it was greater by $2.65 \mathrm{mg} \cdot \mathrm{kg}-1 \mathrm{~d} . \mathrm{m}$ in comparison to Control. A similar result was obtained in Group A, where the difference reached $2.5 \mathrm{mg} \cdot \mathrm{kg}-1 \mathrm{~d} . \mathrm{m}$. These results are statistically significant and have an impact on the research outcome.

Indicated concentrations of $\mathrm{Zn}$ did not show any significant dispersion of values in reference to mean value. Considerable fluctuation of its content in sample material was marked between the group fed sugar syrup with addition of Actara $25 \mathrm{WG}$ and the one fed Thiram Granuflo 80 WG fungicide and the group supplied with Basagran 480 SL (Table 3). The variation of $\mathrm{Zn}$ in bees from subsequent groups was distributed irregularly. Therefore, it may be stated that no set tendency in variation among certain researched groups exists.

Another two elements, i.e., $\mathrm{Cd}$ and $\mathrm{Pb}$, did not represent statistically significant fluctuations within tested groups. Supplied products did not affect the distribution of said elements in the organisms of experimental bees. It may therefore be presumed that the contents of $\mathrm{Cd}$ and $\mathrm{Pb}$ in sample material indicates their presence in the habitat of the bees. It should therefore be explicitly stated that the fungicide Miedzian WP 50, which led to average levels of mortality, had the most significant impact on the content of tested elements in sample material.

\section{Discussion of Results}

An assessment of pollution of the environment has long been one of the world's priority issues. Sources of contamination and the explanation of its origins are 
constantly sought after in order to foresee its long-term effects. Various methods and simulations are applied for said purposes. It is very common to use plants and animals in the process of bio-indication. Honey bees also play an important role here, as they have the ability to indicate climate change or the degree of environmental pollution [22]. There are not only field studies with bees taken directly from the environment, but also laboratory research where external factors that adversely affect the insects are easier to reproduce. In the latter, it is common to use dispenser cages in order to control food intake and mortality.

It has been confirmed that the best results are obtained when applying $20 \mathrm{ml}$ syringes as food dispensers [23]. In the current research, however, $5 \mathrm{ml}$ syringes were used in order to avoid overproduction of pesticide waste. Similar dispensers were used by Ptaszyńska et al. [24] in research on the impact of ethanol on nosema spore-formers, and Pareja et al. [25] in research on the impact of pesticides on bees. Among tested pesticides the highest mortality was observed in the group fed with Actara $25 \mathrm{WG}$, which caused $100 \%$ mortality. Similar results were obtained by Roman et al. [26] during research on the toxicity of various substances against bees.

The same observations were obtained by Laurino et al. [27], who researched the impact of neonicotinoid pesticides on bees of a different genotype. Our own studies show the impact of fungicides on the mortality rate, but in scientific literature these pesticides are without such an effect. Mayer and Lunden [28] tested the fungicides triforine, triflumizole, and DuPont 6573, and the acaricide hexythiazox for honey bee toxicity and their effects on bee foraging. There was no increased mortality in bees in contact with these pesticides. Similar results have been obtained for Ladurner et al. [29] of the impact of fungicides on bees (Osmia lignaria). They noticed reduced female activity and increased mortality.

The study enabled recognition of changes in the behavior of tested insects. It was particularly noticeable in Group D, where bees were fed syrup supplemented with one of the neonicotinoids. Similar behavioral disorder caused by exposure to pesticides has been presented by Thompson [30], whereas Barbieri et al. [31] confirm the influence of neonicotinoids on insects from different systematic groups such as ants. Brandt et al. [32] indicated the severe impact of several pesticides on the immune system of bees. The present study showed the significant impact of pesticides on content of metals in bee organisms. This was particularly high in the case of $\mathrm{Cu}$ in Group A, which clearly resulted from the presence of this element in the provided pesticide. Similarly, an increase of $\mathrm{Fe}$ content was observed, and $\mathrm{Ni}$, during his research on seasonal variations of four trace elements $(\mathrm{Cd}$, $\mathrm{Pb}, \mathrm{Cu}$, and $\mathrm{Se}$ ) also pointed to $\mathrm{Cu}$, whose concentration in bees was the highest even though its level amounted to $22.6 \mathrm{mg} \cdot \mathrm{kg}-1 \mathrm{~d} . \mathrm{m}$., barely exceeding the level obtained Group $\mathrm{K}$ during the present study [33]. This puzzling trend has been observed in the accumulation of $\mathrm{Cd}$.
In bees from all groups, except for Group $\mathrm{D}$, the $\mathrm{Cd}$ content was lower than in Control $\left(0.200 \mathrm{mg} \cdot \mathrm{kg}^{-1}\right.$ d.m.). However, these differences were statistically insignificant. The lower accumulation of $\mathrm{Cd}$ to be obtained in conventional studies is observed in the case of beeswax $(0.01-0.1 \mathrm{mg} / \mathrm{kg}$ ), and in the case of propolis $(0.006-3.8 \mathrm{mg} / \mathrm{kg})$ and pollen $(0.05-2.3 \mathrm{mg} / \mathrm{kg})$. This suggests a certain accumulation of this in the bee body [34]. Hladum et al. [35] indicated that worker bees accumulated all tested elements $(\mathrm{Cd}, \mathrm{Cu}, \mathrm{Pb}$, and $\mathrm{Se})$ in amounts greater than those accumulated by the queen (very little amounts), whereas the concentrations of said elements were highest in the bodies of deceased worker bees.

\section{Conclusions}

The deterioration of health and general condition of honey bee colonies may be caused by pesticides commonly used in agriculture. This study clearly indicates that selected pesticides used for the purpose of plant protection and plant cultivation may adversely affect bee behavior and the accumulation of trace elements in their bodies. Among the tested pesticides, particular attention should be paid to fungicides that are not commonly tested for their effects on the honey organ. Our own studies showed that their effect significantly changed the content of $\mathrm{Cu}$ and negatively affected the survival of bees. The negative impact of insecticides on bees and their behavior have been confirmed. The herbicides and insecticides had their greatest impact on behavior. All selected pesticides changed natural behavior, mortality rates, and accumulation compared to Control.

\section{Acknowledgements}

This project was supported by the Department of Environment Hygiene and Animal Welfare at the Wroclaw University of Environmental and Life Science, and the Wroclaw Centre of Biotechnology's Leading National Research Centre (KNOW) for 2014-18.

\section{References}

1. SATTARI S.Z., BOUWMAN A.F., MARTINEZ RODRÍGUEZ R., BEUSEN A.H.W., ITTERSUM M.K. Negative global phosphorus budgets challenge sustainable intensification of grasslands. Nat. Commun. 7 (10696), 2016.

2. ŁOZOWICKA B., ABZEITOVA E., SAGITOV A., KACZYNSKI P., TOLEUBAYEV K., LI A. Studies of pesticide residues in tomatoes and cucumbers from Kazakhstan and the associated health risks. Environ. Monit. Assess. 187, 609, 2015.

3. ŁOZOWICKA B., JANKOWSKA M., RUTKOWSKA E., HRYNKO I., KACZYŃSKI P., MICIŃSKI J. The evaluation of a fast and simple pesticide multiresidue 
method in various herbs by gas chromatography. J. Nat. Med. 68, 95, 2014.

4. KILJANEK T., NIEWIADOWSKA A., SEMENIUK S., GAWEE M., BORZECCKA M., POSYNIAK A. Multiresidue method for the determination of pesticides and pesticide metabolites in honeybees by liquid and gas chromatography coupled with tandem mass spectrometry - Honeybee poisoning incidents. J. Chromat. A, 1435, 100, 2016.

5. SCHARLAKEN B. GRAAF D.C., MEMMI'S S., DEVREESE B., BEEUMEN J., JACOBS F.J. Differential Protein Expression in the Honey Bee Head After a Bacterial Challenge. Arch. Insect Biochem. Physiol. 65 (4), 223, 2007.

6. MULLIN Ch.A., FRAZIER M., FRAZIER J.L., ASHCRAFT S., SIMONDS R., ENGELSDORP D., PETTIS J.S. High Levels of Miticides and Agrochemicals in North American Apiaries: Implications for Honey Bee Health. PLoS ONE 5 (3), 2010.

7. ENGELSDORP D., EVANS J.D., SAEGERMAN C., MULLIN CH., HAUBRUGE E., NGUYEN B.K., FRAZIER M., FRAZIER J., COX-FOSTER D., CHEN Y., UNDERWOOD R., TARPY D.R., PETTIS J.S. Colony Collapse Disorder: A Descriptive Study. PLoS ONE 4 (8), 2009.

8. BRODERICK N.A., RAFFA K.F., HANDELSMAN J. Midgut bacteria required for Bacillus thuringiensis insecticidal activity. PNAS, 103 (41), 15196, 2006.

9. YANG E.C., CHUANG Y.C., CHEN Y.L., CHANG L.H. Abnormal Foraging Behavior Induced by Sublethal Dosage of Imidacloprid in the Honey Bee (Hymenoptera: Apidae). J. Econ. Entomol. 101 (6), 1743, 2008.

10. HENRY M., BÉGUIN M., REQUIER F., ROLLIN O., ODOUX J. F., AUPINEL P., APTEL J., TCHAMITCHIAN S., DECOURTYE A. A Common Pesticide Decreases Foraging Success and Survival in Honey Bee: Science 336, 348, 2012.

11. SANCHEZ-BAYO F., GOKAK K. Pesticide Residues and Bees - A Risk Assessment. PLoS ONE, 9 (4), 2014.

12. ROMAN A., MADRAS-MAJEWSKA B., POPIELA E. Comparative study of selected toxic elements in propolis and honey. J. Apicult. Sci. 55 (2), 97, 2011.

13. COATES C.J., NAIRN J. Diverse immune functions of hemocyanins. Dev. Comp. Immunol. 45, 43, 2014.

14. SOVIK E., PERRY C.J., LAMORA A., BARRON A.B., BEN-SHAHAR Y. Negative impact of manganese on honeybee foraging. Biol. Lett. 11, $20140989,2015$.

15. ZARIC N.M., ILIJEVIC K., STANISAVLJEVIC L., GRZETIC I. Metal concentrations around thermal power plants, rural and urban areas using honeybees (Apis mellifera L.) as bioindicators. Int. J. Environ. Sci. Technol. 13, 413, 2016.

16. BOGDANOV S., HALDIMANN M., LUGINBUH W., GALLMANN P. Minerals in Honey: environmental, geographical and botanical aspects. J Apicult. Res. Bee World 46 (4), 269, 2007.

17. NIELSEN F.H. Ultratrace elements in nutrition. Annu. Rev. Nutr. 4, 21, 1984.

18. ZUGRAVU C.A., PARVU M., PATRASCU D., STOIAN A. Correlations between lead and cadmium pollution of honey and environmental heavy metal presence in two Romanian counties. Bull. UASVM Agric. 66, 230, 2009.

19. EVANS J.D., SPIVAK M. Socialized medicine: individual and communal disease barriers in honey bees. J. Invert. Pathol. 103 (S), 62, 2010.
20. CZEKOŃSKA K. Influence of carbon dioxide on Nosema apis infection of honey bees (Apis mellifera L.). J. Invert. Pathol. 95 (2), 84, 2007.

21. STABENTHEINER A. KOVAC H. BRODSCHNEIDER R. Honey bee colony thermoregulation - regulatory mechanisms and contribution of individuals in dependence on age, location and thermal stress. PLoS ONE 5 (1), 2010.

22. ZHELYAZKOVA I. Honeybees - bioindicators for environmental quality. Bulg. J. Agric. Sci. 18 (3), 435, 2012.

23. HUANG S.K., CSAKI T., DOUBLET V., DUSSAUBAT C., EVANS J.D., GAJDA A.M., GREGORC A., HAMILTON M.C., KAMLER M., LECOCQ A., MUZM.N., NEUMANN P., ZKIRIM A., SCHIESSER A.N., SOHR A.R., TANNER G., TOZKAR C.Z., WILLIAMS G.R., WU L., ZHENG H., CHEN Y.P. Evaluation of Cage Designs and Feeding Regimes for Honey Bee (Hymenoptera: Apidae) Laboratory Experiments. J. Econ. Entomol. 107 (1), 54, 2014.

24. PTASZYŃSKA A.A., BORSUK G., MULENKO W., OLSZEWSKI K. Impact of ethanol on Nosema spp. infected bees. Med. Wet. 69, 12, 2013.

25. PAREJA L., COLAZZO M., PEREZ-PARADA A., NIELL S., CARRASCO-LETELIER L., BESIL N., CESIO, M. V., HEINZEN H. Detection of Pesticides in Active and Depopulated Beehives in Uruguay. Int. J. Environ. Res. Public Health. 8 (10), 3844, 2011

26. ROMAN A., POPIELA-PLEBAN E., MIGDAŁ P. Wpływ wybranych środków do zwalczania komarów oraz insektycydów stosowanych w ochronie roślin na pszczołę miodną. Effect of some mosquitocidal agents and plant protection insecticides on honeybees. Przem. Chem. 95 (1), 125, 2016.

27. LAURINO D., MANINO A., PATETTA A., PORPORATO $M$. Toxicity of neonicotinoid insecticides on different honey bee genotypes. Bul. Insect. 66 (1), 119, 2013.

28. MAYER D.F., LUNDEN J.D. Toxicity of Fungicides and an Acaricide to Honey Bees (Hymenoptera: Apidae) and their Effects on Bee Foraging Behavior and Pollen Viability on Blooming Apples and Pears. Environ. Entomol. 15 (5), 1047, 1986.

29. LADURNER E., BOSCH J., KEMP W.P., MAINI S. Foraging and Nesting Behavior of Osmia lignaria (Hymenoptera: Megachilidae) in the Presence of Fungicides: Cage Studies Full Access. J. Econ. Entomol. 101 (3), 647, 2008.

30. THOMPSON H.M. Behavioural Effects of Pesticides in Bees - Their Potential for USA in Risk Assessment. Ecotoxicology, 12, 317, 2003.

31. BARBIERI R.F., LESTER P.J., MILLER A.S., RYAN K.G. A neurotoxic pesticide changes the outcome of aggressive interactions between native and invasive ants. Proc. R. Soci. Biol. 280 (1772), 2013.

32. BRANDT A., GORENFLO A., SIEDE R., MEIXNER M., BUCHLER R. The neonicotinoids thiacloprid, imidacloprid, and clothianidin affect the immunocompetence of honey bees (Apis mellifera L.). J. Insect Physiol. 86, 40, 2016.

33. ROMAN A. The Level of Copper, Selenium, Lead and Cadmium in Forager Bees in Two Regions and Subsequent Seasons of the Year. Pol. J. Environ. Stud. 19 (3), 663, 2010.

34. BOGDANOV S. Contaminants of bee products. Apidologie 37 (1), $1,2006$.

35. HLADUN K.R., DI N., LIU T.X., TRUMBLE J.T. Metal contaminant accumulation in the hive: consequences for whole-colony health and brood production in the honey bee (Apis mellifera L.). Environ. Toxicol. Chem. 35 (2), 322, 2015. 